\title{
Penerapan Pembelajaran Matematika melalui Model Tutor Sebaya dengan Pendekatan Saintifik sebagai Upaya Meningkatkan Pemahaman Konsep dan Motivasi Belajar Siswa di Kelas Inklusif
}

\author{
Zahrotur Rohmah \\ Pendidikan Matematika Universitas Islam Negeri Sunan Kalijaga Yogyakarta \\ e-mail : zahroturrohmah08@gmail.com
}

\begin{abstract}
ABSTRAK. Penelitian ini bertujuan untuk mengetahui penerapan pembelajaran matematika melalui model tutor sebaya dengan pendekatan saintifik yang dapat meningkatkan pemahaman konsep dan motivasi belajar siswa di kelas inklusif. Jenis penelitian ini adalah Penelitian Tindakan Kelas (PTK). Subjek penelitian ini yaitu siswa kelas VII E SMP Negeri 2 Sewon Bantul semester genap tahun ajaran 2018/2019 yang berjumlah 30 siswa dengan satu siswa dengan gangguan penglihatan (tunanetra) dalam kategori anak kurang awas atau low vision. Penelitian ini dilaksanakan pada siklus I dan siklus II. Hasil penelitian menunjukkan bahwa penerapan pembelajaran matematika melalui model tutor sebaya dengan pendekatan saintifik dapat meningkatkan pemahaman konsep dan motivasi belajar siswa di kelas inklusif yaitu kelas VII E SMP Negeri 2 Sewon. Peningkatan pemahaman konsep dapat dilihat dari persentase rata-rata kelas dalam tes pemahaman konsep siswa siklus I yaitu 45\% menjadi 75\% pada siklus II dan persentase rata-rata kelas dalam motivasi belajar mencapai $69 \%$ pada siklus I menjadi $70 \%$ pada siklus II. Tahapan proses pembelajaran yaitu mengamati, menanya, mengumpulkan informasi, mengasosiasikan, dan mengkomunikasikan. Proses pembelajaran dilaksanakan berkelompok dengan bantuan tutor sebaya. Pembelajaran yang dilaksanakan seperti pembelajaran pada umumnya sekaligus mengimplementasikan prinsip-prinsip khusus untuk siswa tunanetra dengan mempertimbangkan adanya siswa low vision.
\end{abstract}

Kata Kunci: kelas inklusif, model tutor sebaya, pendekatan saintifik, pemahaman konsep, motivasi belajar.

\section{PENDAHULUAN}

Undang-Undang Sistem Pendidikan Nasional Nomor 20 Tahun 2003 Pasal 11 Ayat 1 menyatakan bahwa pemerintah dan pemerintah daerah wajib memberikan layanan dan kemudahan, serta menjamin terselenggaranya pendidikan yang bermutu bagi warga negara tanpa diskriminasi. Implementasi dari Undang-Undang tersebut yaitu Pemerintah Negara Indonesia sejak awal tahun 2000 telah mengembangkan program pendidikan inklusif yang merupakan kelanjutan dari program pendidikan terpadu yang pernah dikembangkan pada tahun 1980-an. Pada tahun 2004 Indonesia menyelenggarakan konvensi nasional yang menghasilkan Deklarasi Bandung dengan komitmen Indonesia menuju pendidikan inklusif (Garnida, 2015).

SMP Negeri 2 Sewon merupakan salah satu sekolah yang ditunjuk sebagai Sekolah Penyelenggara Pendidikan Inklusi (SPPI) berdasarkan Surat Keputusan Nomor 36/KPTS/2013 pada tanggal 30 April 2013. Seiring berkembangnya program pendidikan inklusif, jumlah ABK (Anak Berkebutuhan Khusus) di SMP Negeri 2 Sewon tahun 2019 mencapai 30 siswa, dengan beragam jenis kebutuhan khusus, di antaranya tunanetra (tunanetra total dan low vision), tunarungu, slow learner, dan autis. 
Kelas VII E merupakan salah satu kelas di SMP Negeri 2 Sewon yang terdapat satu siswa dengan gangguan penglihatan (tunanetra) termasuk dalam kategori anak kurang awas (low vision) yang hanya mampu melihat dengan jarak pandang satu meter. Dalam pembelajaran, siswa low vision menggunakan bantuan kaca pembesar serta membutuhkan bantuan teman untuk membacakan materi yang dituliskan pada papan tulis.

Permasalahan pada saat pembelajaran matematika di kelas VII E yaitu kurangnya kemampuan guru dalam berkomunikasi dengan anak berkebutuhan khusus serta kurangnya bantuan Guru Pembimbing Khusus (GPK) saat pembelajaran. Hal ini penulis peroleh dari hasil wawancara singkat kepada Ibu Wagiyem selaku guru matematika di SMP Negeri 2 Sewon pada tanggal 14 November 2018. Guru pembimbing khusus di SMP Negeri 2 Sewon merupakan salah satu guru di Sekolah Luar Biasa (SLB). Guru Pembimbing Khusus hanya hadir di SMP Negeri 2 Sewon pada hari Selasa dan hari Jumat.

Nilai Ulangan Akhir Semester Ganjil Tahun Ajaran 2018/2019 siswa kelas VII E memiliki nilai rata-rata kelas yaitu 37 berada di bawah nilai rata-rata sekolah sebesar 40. Informasi tersebut dikuatkan dengan pernyataan guru mata pelajaran matematika pada saat wawancara bahwa sebagian besar siswa kesulitan dalam memahami serta menerapkan konsep matematika dengan tepat, sehingga menjadikan siswa kesulitan dalam mengerjakan soal. Kebanyakan siswa kesulitan mengerjakan soal yang lebih kompleks dan berbeda dengan contoh yang diberikan oleh guru.

Permasalahan-permasalahan lain diketahui berdasarkan observasi dan wawancara diantaranya: siswa kurang memiliki kesadaran untuk mengerjakan tugas dari guru. Hal ini terlihat ketika guru memberikan instruksi untuk mengerjakan soal yang ada di LKS, hanya beberapa siswa yang menjalankan tugas dengan antusias. Sebagian siswa yang lain tidak mengerjakan tugas dan mengajak bercanda teman yang lain. Hasil wawancara yang dilakukan penulis dengan siswa yang tidak mengerjakan tugas yaitu karena siswa belum faham dengan materi yang terkait serta tidak mampu memahami soal, hal tersebut mengakibatkan siswa enggan mengerjakan serta kurang percaya diri untuk mencoba mengerjakan soal, sehingga siswa lebih memilih menyontek pekerjaan siswa lain. Keengganan tersebut berujung pada tidak dibukanya LKS matematika bahkan siswa asik bermain dengan temannya. Pada saat guru menerangkan, banyak siswa yang mengobrol dengan siswa lain dan hanya beberapa siswa yang memperhatikan penjelasan guru dengan seksama.

Dari uraian di atas maka terdapat permasalahan yang perlu ditangani yaitu pemahaman konsep dan motivasi belajar siswa. Motivasi belajar merupakan hal penting bagi siswa dalam pembelajaran sebagai wujud keinginan serta kemauan siswa dalam belajar. Motivasi belajar yang tinggi akan menumbuhkan semangat belajar, sehingga siswa memiliki kecenderungan mudah dalam memahami materi. Pemahaman konsep merupakan hal penting dalam pembelajaran matematika. Kesalahan dalam pemahaman konsep matematika merupakan hal yang sangat fatal, mengingat pemahaman konsep dalam matematika merupakan suatu rangkaian dan berkesinambungan.

Penelitian yang dilakukan oleh Suci Yuniati dan Arnida Sari (Sari \&Yuniati, 2018)menunjukkan bahwa pembelajaran matematika menggunakan pendekatan Realistic Mathematics Education (RME) lebih efektif daripada model pembelajaran konvensional terhadap pemahaman konsep siswa kelas VII MTsNegeri Danau Bingkuang. Penelitian untuk kemampuan pemahaman konsep juga (Kurniati\& Sari, 2019) yang menunjukkan hasil bahwa model pembelajaran kooperatif tipe Numbered Heads Together (NHT) mampu meningkatkan kemampuan pemahaman konsep matematis ditinjau dari kemandirian belajar.

Ada pokok bahasan dalam matematika yang menjadi prasyarat bagi pokok bahasan lain. Karena konsep-konsep dalam matematika tersusun secara sistematis, hirarkis, dan logis (Retnowati\&Murtiyasa, 2013). Segiempat merupakan salah satu pokok bahasan prasyarat bagi pokok bahasan selanjutnya yang tergabung dalam lingkup geometri. Oleh karena itu, 
pembelajaran di kelas harus mamberikan pemahaman konsep yang tepat. Sehingga konsepkonsep dalam segiempat nantinya dapat dikonstruk secara mandiri oleh pada pokok bahasan lain.

Selain permasalahan tersebut, penulis juga melihat potensi siswa yang dapat dikembangkan guna membantu guru pada saat pembelajaran, yaitu ada beberapa siswa yang menonjol saat pembelajaran matematika. Siswa yang menonjol tersebut diminta untuk memberikan arahan kepada siswa lain. Dengan potensi tersebut, penulis ingin melakukan penelitian dengan menerapkan model tutor sebaya pada saat pembelajaran matematika. Penggunaan model pembelajaran tutor sebaya juga mempertimbangkan siswa low vision yang membutuhkan bantuan orang lain dalam pembelajaran. Model tutor sebaya merupakan bagian dari cooperative learning atau belajar bersama, dimana siswa yang kurang mampu dibantu temannya sendiri yang lebih mampu dalam suatu kelompok. Hal ini diharapkan pembelajaran dapat berjalan dan lebih efektif. Selain itu, dengan tutor sebaya mengajarkan siswa untuk belajar mandiri tidak bergantung pada materi yang disampaikan oleh guru.

Penelitian serupa (Noryanti, Mz, \&Nufus, 2019) menunjukkan bahwa metode tutor sebaya lebih efektif daripada model pembelajaran langsunguntuk meningkatkan kemampuan pemecahan masalah. Analisis data yang dilakukan menunjukkan perolehan rata-rata nilai pada kelas eksperimen adalah 74,89, sedangkan rata-rata nilai pada kelas kontrol adalah 68,68. Hal ini menunjukkan bahwa kelas yang menggunakan metode tutor sebaya lebih efektif dalam mempengaruhi kemampuan pemecahan masalah matematis secara positif dibandingkan dengan kelas yang menggunakan metode pembelajaran langsung.

SMP Negeri 2 Sewon menggunakan Kurikulum 2013 saat pembelajaran. Pembelajaran pada Kurikulum 2013 menggunakan pendekatan saintifik atau berbasis proses keilmuan (Musfiqon\&Nurdyansyah, 2015). Dengan pendekatan saintifik, siswa diajarkan agar mencari tahu dari berbagai sumber melalui kegiatan mengamati, menanya, mengumpulkan informasi, mengasosiasikan, serta mengkomunikasikan informasi. Siswa diminta untuk mengkonstruk sendiri pengetahuan, pemahaman, serta skill dari proses belajar yang dilakukan, sehingga informasi yang diperoleh dapat melekat dalam ingatan. Dengan kegiatan tersebut proses pembelajaran terpusat pada siswa sesuai dengan paradigma kurikulum 2013 yaitu peserta didik aktif mengkontruksi pengetahuannya sendiri (Musfiqon\&Nurdyansyah, 2015).

Penulisberencana melakukan penelitian dengan menerapkan model tutor sebaya dengan pendekatan saintifik sebagai upaya meningkatkan pemahaman konsep dan motivasi belajar siswa di kelas inklusif.

\section{METODE}

Penelitian ini merupakan penelitian tindakan kelas (PTK) atau classroom action research dengan model penelitian tindakan Kurt Lewin yang telah dikembangkan oleh Stephen Kemmis dan Robin Mc Taggart. Desain penelitian yang diterapkan dalam penelitian tindakan ini terdapat empat tahap dalam setiap siklusnya, yaitu perencanaan, tindakan, observasi dan refleksi. Subjek penelitian ini adalah siswa kelas VII E SMP Negeri 2 Sewon Tahun ajaran 2018/2019 yang terdiri dari 30 siswa (12 siswa perempuan dan 18 siswa laki-laki) dengan satu siswa low vision yang termasuk dalam anak berkebutuhan khusus dengan gangguan penglihatan (tunanetra).

Jenis data yang digunakan dalam penelitian ini yaitu data kuantitatif dan kualitatif. Data dikumpulkan dengan observasi keterlaksanaan pembelajaran, wawancara, teknik skala untuk mengukur motivasi belajar, tes untuk mengukur kemampuan pemahaman konsep siswa serta teknik dokumentasi untuk mendokumentasikan aktivitas siswa serta guru saat pembelajaran. Data yang telah terkumpul kemudian dianalisis menggunakan analisis data kuantitatif dan kualitatif. Analisis data hasil tes pemahaman konsep dilakukan dengan memberikan nilai pada pekerjaan siswa sesuai pedoman penskoran kemudian diolah dengan rumus (Sudijono, 2012) dan dihitung persentasenya. 
Keterangan:

$$
\begin{gathered}
M_{x}=\frac{\Sigma f x^{\prime}}{N} \\
\text { Persentase }(\mathrm{P})=\frac{\text { rata-rata } \text { kelas }}{\text { rata-rata } \text { maksimal }} \times 100 \%
\end{gathered}
$$

$$
\begin{array}{ll}
M_{x} & : \text { Mean/rata-rata hitung } \\
f & : \text { frekuensi nilai } \\
x^{\prime} & : \text { titik tengah } \\
N & \text { : banyak data }
\end{array}
$$

Sedangkan data motivasi belajar dianalisis dengan menggumpulkan butir pernyataan sesuai aspek kemudian diberi skor dan diinterpretasikan sesuai kategori pada Tabel 1:

Tabel 1. Kategori Persentase skor yang dicapai

\begin{tabular}{cc}
\hline Persentase skor yang dicapai & Kategori \\
\hline $80,00 \% \leq \mu \leq 100 \%$ & Sangat Tinggi \\
$60 \% \leq \mu \leq 79,99 \%$ & Tinggi \\
$40 \% \leq \mu \leq 59,99 \%$ & Sedang \\
$20 \% \leq \mu \leq 39,99 \%$ & Rendah \\
$0 \% \leq \mu \leq 19,99 \%$ & Sangat Rendah \\
\hline
\end{tabular}

Penelitian ini dikatakan berhasil jika memenuhi indikator sebagai berikut.

a. Persentase rata-rata kelas dalam tes pemahaman konsep meningkat dari siklus sebelumnya dan persentase tiap indikator dalam kategori baik. Dikatakan baik apabila persentase tersebut berada pada interval rentang $60,00 \leq \mu \leq 79,99$.

Persentase rata-rata kelasdalam motivasi belajar siswa meningkat dari siklus sebelumnya dan persentase tiap indikator dalam kategori tinggi. Dikatakan tinggi apabila persentase tersebut berada pada interval rentang $60,00 \leq \mu \leq 79,99$.

\section{HASIL DAN PEMBAHASAN}

\section{Siklus I}

\section{Hasil Analisis Kuantitatif}

Pada siklus I dilaksanakan tes kemampuan pemahaman konsep dan pengisian skala motivasi belajar. Tes dilaksanakan setelah penyampaian materi selama dua pertemuan. Data hasil tes pemahaman konsep siklus I dapat dilihat pada Tabel 2:

Tabel 2. Statistik Nilai Tes Pemahaman Konsep Siklus I

\begin{tabular}{cc}
\hline Sebaran Data & Nilai \\
\hline Jumlah Siswa & 30 \\
Skor ideal & 100 \\
Nilai minimum & 21 \\
Nilai Maksimum & 79 \\
Nilai rata-rata & 51.76 \\
\hline
\end{tabular}

Dari Tabel 2 tersebut diketahui bahwa nilai rata-rata siswa kelas VII E setelah diterapkan pembelajaran dengan model tutor sebaya dengan pendekatan saintifik mencapai 51.76. Adapun ketercapaian indikator pemahaman konsep pada Tabel 3: 
Tabel 3. Ketercapaian Indikator Pemahaman Konsep Siklus I

\begin{tabular}{|c|c|c|c|}
\hline & Indikator Pemahaman Konsep & $\begin{array}{r}\text { Ketercapaian } \\
\text { Indikator }(\%)\end{array}$ & Kategori \\
\hline P1 & Menyatakan ulang suatu konsep & $73.6 \%$ & Baik \\
\hline P2 & $\begin{array}{l}\text { Mengklasifikasi objek-objek } \\
\text { berdasarkan konsep matematika }\end{array}$ & $51.9 \%$ & Sedang \\
\hline P3 & $\begin{array}{l}\text { Menerapkan konsep secara algoritma } \\
\text { atau jelas }\end{array}$ & $58 \%$ & Sedang \\
\hline P4 & $\begin{array}{l}\text { Memberikan contoh dan non contoh } \\
\text { dari suatu konsep }\end{array}$ & $43.3 \%$ & Sedang \\
\hline P5 & $\begin{array}{l}\text { Menyajikan konsep dalam berbagai } \\
\text { representasi }\end{array}$ & $45.8 \%$ & Sedang \\
\hline \multirow[t]{2}{*}{ P6 } & $\begin{array}{l}\text { Mengaitkan berbagai konsep } \\
\text { matematika }\end{array}$ & $38 \%$ & Kurang baik \\
\hline & Rata-rata & $51.76 \%$ & Sedang \\
\hline
\end{tabular}

Motivasi belajar siswa diperoleh dari lembar skala yang diberikan kepada siswa setelah mengerjakan evaluasi siklus I. Hasil motivasi belajar siswa berada pada kategori tinggi dengan persentase rata-rata 69\%. Aspek kesadaran siswa dalam belajar matematika memperoleh persentase terendah dari aspek motivasi yang lain. Keempat aspek motivasi tersebut berada pada kategori tinggi.

Tabel 4. Ketercapaian Motivasi Belajar Siswa Siklus I

\begin{tabular}{cccc}
\hline No & Aspek & Persentase & Kategori \\
\hline $\mathbf{1}$ & Perasaan Senang & $71 \%$ & Tinggi \\
$\mathbf{2}$ & Kemauan & $71 \%$ & Tinggi \\
$\mathbf{3}$ & Kesadaran & $66 \%$ & Tinggi \\
$\mathbf{4}$ & Kemandirian & $70 \%$ & Tinggi \\
\hline & Rata-rata & $69 \%$ & Tinggi \\
\hline
\end{tabular}

\section{Hasil Analisis Kualitatif}

Pelaksanaan pembelajaran matematika melalui model tutor sebaya dengan pendekatan saintifik pada siklus I masih banyak kekurangan-kekurangan yang perlu diperbaiki. Penulis bersama guru pengampu matematika berdiskusi mengenai kekurangan siklus I dan perbaikan-perbaikan yang perlu dilakukan, sehingga pembelajaran siklus selanjutnya akan lebih baik dari pembelajaran siklus I. Kekurangan-kekurangan pada pembelajaran siklus I, diantaranya:

a) Siswa belum terbiasa mengikuti pembelajaran secara berkelompok dan berdiskusi, sehingga ada beberapa kelompok yang anggota kelompoknya pasif dan sebagian anggota kelompok tidak menerima pembagian kelompok yang telah dibuat oleh penulis.

b) Suasana kelas ramai dan beberapa siswa berdiskusi di luar topik pembahasan, sehingga proses diskusi berjalan lambat serta menghabiskan waktu yang lama.

c) Penulis kurang memberikan feedback dalam pembelajaran terutama dalam pengerjaan latihan soal.

d) Pada saat evaluasi, ada beberapa siswa yang tidak mengerjakan soal secara keseluruhan.

e) Beberapa siswa tidak menuliskan satuan untuk keliling ataupun luas, mereka hanya fokus pada perhitungan angka.

f) Sebagian besar siswa tidak menuliskan apa yang diketahui dan ditanyakan pada soal. Mereka langsung memberikan uraian jawaban. 
Kekurangan-kekurangan pada pembelajaran siklus I dijadikan sebagai bahan refleksi bagi penulis untuk melakukan perbaikan pembelajaran yang akan dilakukan pada siklus II. Dengan perbaikan tersebut, diharapkan pembelajaran siklus II lebih baik dari pembelajaran siklus I. Rencana perbaikan yang akan dilakukan oleh penulis dalam pembelajaran siklus II sebagai berikut:

1. Mengupayakan agar siswa lebih aktif dalam diskusi kelompok serta mengoptimalkan fungsi tutor dalam pembelajaran. Penulismengintruksikan kepada tutor untuk membantu anggota kelompok dalam memahami materi.

2. Penulis memberikan feedback dalam pembelajaran terutama pada pembahasan latihan soal yang diberikan.

3. Penulismengingatkan siswa untuk menuliskan apa yang diketahui dan apa yang ditanyakan dalam soal yang telah diberikan.

4. Penulismemberikan motivasi pada siswa untuk selalu belajar dan berusaha.

\section{Siklus II}

\section{Hasil Analisis Kuantitatif}

Pembelajaran pada siklus II terdiri dari dua pertemuan. Satu pertemuan penyampaian materi dan satu pertemuan tes. Hasil tes pemahaman konsep pada siklus II sebagai berikut:

Tabel 5. Statistik Nilai Tes Pemahaman Konsep Siklus II

\begin{tabular}{cc}
\hline Jumlah siswa & $\mathbf{3 0}$ \\
\hline Skor ideal & 100 \\
Nilai minimum & 20 \\
Nilai Maksimum & 98 \\
Nilai rata-rata & 75 \\
\hline
\end{tabular}

Dari tabel tersebut diketahui bahwa nilai rata-rata tes pemahaman konsep kelas VII E adalah 75. Ketercapaian pemahaman konsep pada siklus II dapat dilihat dari tabel berikut:

Tabel 6. Ketercapaian Indikator Pemahaman Konsep Siklus II

\begin{tabular}{clcc}
\hline & Indikator Pemahaman Konsep & $\begin{array}{c}\text { Ketercapaian Indikator } \\
\mathbf{( \% )}\end{array}$ & Kategori \\
\hline P1 & $\begin{array}{l}\text { Menyatakan ulang suatu konsep } \\
\text { Pengklasifikansi objek-objek } \\
\text { berdasarkan konsep matematika }\end{array}$ & $96.56 \%$ & Sangat Baik \\
P3 & $\begin{array}{l}\text { Menerapkan konsep secara algoritma } \\
\text { atau jelas }\end{array}$ & $82.96 \%$ & Sangat Baik \\
P4 & $\begin{array}{l}\text { Memberikan contoh dan non contoh } \\
\text { dari suatu konsep }\end{array}$ & $77.16 \%$ & Sangat Baik \\
P5 & $\begin{array}{l}\text { Menyajikan konsep dalam berbagai } \\
\text { representasi } \\
\text { Mengaitkan berbagai konsep } \\
\text { matematika }\end{array}$ & $66.67 \%$ & Baik \\
\hline Rata-rata & $69.44 \%$ & Baik \\
\hline
\end{tabular}

Motivasi belajar siswa diperoleh dari lembar skala yang diberikan kepada siswa setelah mengerjakan evaluasi siklus I. Hasil motivasi belajar siswa berada pada kategori tinggi dengan persentase rata-rata 70\%. Aspek kesadaran siswa dalam belajar matematika memperoleh persentase terendah dari aspek motivasi yang lain, sedangkan aspek perasaan senang mencapai 
persentase tertinggi dari yang lain yaitu 73\%. Keempat aspek motivasi tersebut berada pada kategori tinggi. Berikut merupakan tabel persentase motivasi belajar siklus II.

Tabel 7. Ketercapaian Motivasi Belajar Siswa Siklus II

\begin{tabular}{cccc}
\hline No & Aspek & Persentase & Kategori \\
\hline 1 & Perasaan Senang & $73 \%$ & Tinggi \\
2 & Kemauan & $69 \%$ & Tinggi \\
3 & Kesadaran & $67 \%$ & Tinggi \\
4 & Kemandirian & $71 \%$ & Tinggi \\
\hline & Rata-rata & $70 \%$ & Tinggi \\
\hline
\end{tabular}

\section{Analisis Kualitatif}

Berdasarkan tabel 2 dan tabel 6 , indikator pemahaman siswa mengalami peningkatan dari siklus I ke siklus II dan berada pada kategori baik. Secara lebih jelas, ketercapaian pemahaman konsep dapat dilihat pada diagram berikut.

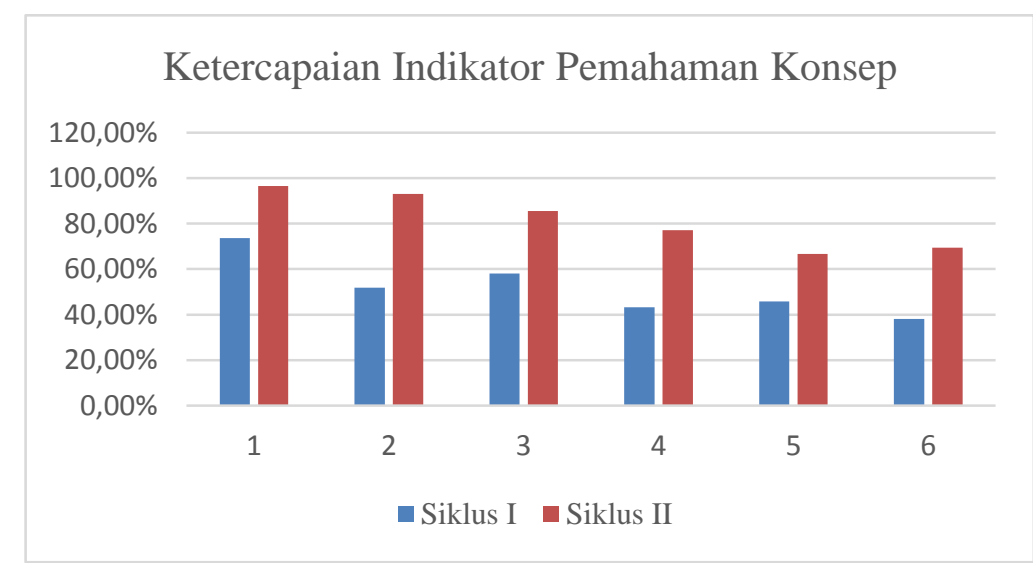

Gambar 1. Diagram Ketercapaian Indikator Pemahaman Konsep

Berdasarkan tabel 3 dan tabel 6 , aspek motivasi belajar siswa mengalami peningkatan dari siklus I ke siklus II kecuali aspek kemauan yang mengalami penurunan. Namun secara keseluruhan, rata-rata motivasi belajar mengalami peningkatan sebesar 1\%. Untuk lebih jelasnya, peningkatan mtivasi belajar siswa dapat dilihat pada diagram berikut.

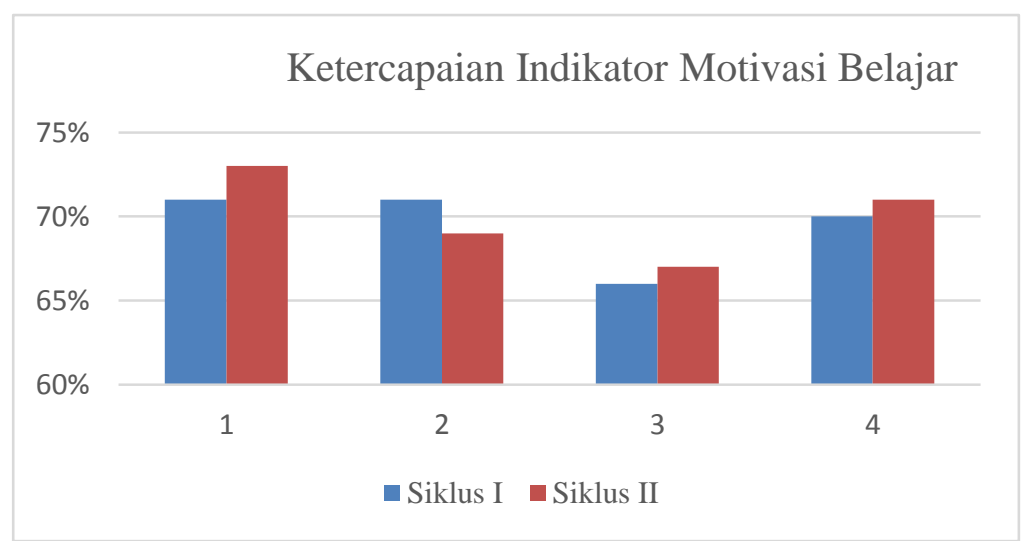

Gambar 2. Diagram Ketercapaian Indikator Motivasi Belajar

Kegiatan refleksi ini berupa menganalisis hasil tes pemahaman konsep dan motivasi belajar siswa dengan dibandingkan dengan indikator keberhasilan penelitian. Indikator keberhasilan penelitian yaitu rata-rata kelas dalam tes pemahaman konsep meningkat dari siklus sebelumnya dan 
persentase tiap indikator dalam kategori baik serta persentase rata-rata kelas dalam motivasi belajar siswa minimal berada dalam kategori tinggi dan mengalami peningkatan dari siklus I ke siklus selanjutnya.

Tabel 8. Indikator Keberhasilan Penelitian

\begin{tabular}{|c|c|c|c|}
\hline \multirow{2}{*}{ Indikator Keberhasilan } & \multicolumn{2}{|c|}{ Hasil persentase } & \multirow{2}{*}{ Kesimpulan } \\
\hline & Siklus I & Siklus II & \\
\hline $\begin{array}{l}\text { Persentase rata-rata kelas dalam } \\
\text { tes pemahaman konsep } \\
\text { meningkat dari siklus sebelumnya } \\
\text { dan persentase tiap indikator } \\
\text { dalam kategori baik. Dikatakan } \\
\text { baik apabila persentase tersebut } \\
\text { berada pada interval rentang } \\
60,00 \leq \mu \leq 79,99 \text {. }\end{array}$ & $\mu=45 \%$ & $\mu=75 \%$ & $\begin{array}{l}\text { Rata-rata meningkat } 30 \% \\
\text { dari siklus sebelumnya dan } \\
\text { tiap indikator berada } \\
\text { dalam kategori baik. }\end{array}$ \\
\hline $\begin{array}{l}\text { Persentase rata-rata kelas dalam } \\
\text { motivasi belajar siswa meningkat } \\
\text { dari siklus sebelumnya dan } \\
\text { persentase tiap indikator dalam } \\
\text { kategori tinggi. Dikatakan tinggi } \\
\text { apabila persentase tersebut berada } \\
\text { pada interval rentang } 60,00 \leq \\
\mu \leq 79,99 \text {. }\end{array}$ & $\begin{array}{c}\mu=69 \% \\
\text { (Tinggi) }\end{array}$ & $\begin{array}{c}\mu=70 \% \\
\text { (Tinggi) }\end{array}$ & $\begin{array}{l}\text { Rata-rata meningkat } 1 \% \\
\text { dari siklus sebelumnya dan } \\
\text { tiap indikator berada } \\
\text { dalam kategori baik. }\end{array}$ \\
\hline
\end{tabular}

Karena tercapainya kedua indikator keberhasilan tersebut, maka penelitian dapat diberhentikan. Beberapa hal yang dianggap menjadi kesuksesan siklus II ini adalah sebagai berikut.

a. Siswa mulai terbiasa dengan proses belajar kelompok dan berdiskusi.

b. Kegiatan pembelajaran dengan pendekatan saintifik mendorong siswa untuk berusaha mengkonstruksi konsep secara mandiri.

Pembelajaran melalui model tutor sebaya mendorong siswa untuk saling diskusi serta mendorong siswa untuk bertanya.

\section{PEMBAHASAN}

Pembelajaran matematika yang menerapkan model tutor sebaya dengan pendekatan saintifik dalam penelitian ini terlaksana dalam dua siklus, siklus I dan siklus II. Pelaksanaan model pembelajaran tutor sebaya yang terpenting yaitu mempersiapkan tutor untuk membimbing temannya. Pemilihan tutor dalam penelitian ini sesuai dengan pendapat Anggorowati (Anggorowati, 2013) yaitu memiliki kemampuan akademis di atas rata-rata dalam satu kelas, mampu menjalin kerja sama dengan sesama siswa, suka membantu sesamanya yang mengalami kesulitan. Selain itu, penulis meminta pertimbangan dari guru pengampu mata pelajaran matematika di kelas, yang mana guru tersebut telah memahami karakter serta kemampuan siswa dalam pelajaran matematika.

Pembelajaran matematika materi segiempat diajarkan dengan memanfaatkan media pembelajaran berupa bangun-bangun segiempat. Penggunaan media tersebut mempertimbangkan adanya siswa tunanetra yang termasuk dalam kategori siswa low vision. Siswa tunanetra lebih banyak belajar melalui pendengaran dan perabaan. Bagi siswa tunanetra, untuk mengetahui dunia sekelilingnya harus menggunakan benda konkrit yang dapat diraba (Garnida, 2015). Penggunaan media pembelajaran tersebut sesuai dengan prinsip kekonkritan. Pembelajaran yang dilakukan di kelas inklusif dengan berbantuan media juga sebagai perwujudan prinsip belajar sambil 
melakukan, dimana siswa low vision dan siswa yang lain melakukan pengamatan, perhitungan sehingga memperoleh konsep dari keliling dan luas segiempat.

Sistem penilaian dalam pendidikan inklusif mengacu pada pengembangan kurikulum yang digunakan (Garnida, 2015). Tiga kemungkinan proses penilaian bagi anak berkebutuhan khusus, yaitu 1) mengikuti kurikulum umum yang berlaku untuk peserta didik pada umumnya di sekolah 2) Mengikuti kurikulum yang sudah dimodifikasi dan 3) mengikuti kurikulum rencana pembelajaran individualisasi. Sistem penilaian yang dilakukan bagi siswa kebutuhan khusus low vision di kelas VII E mengikuti kurikulum umum yang berlaku yaitu menggunakan kriteria penilaian reguler sepenuhnya. Agar siswa low vision menguasai kompetensi dasar, guru yang mengajar di kelas inklusif harus mengimplementasikan prinsip-prinsip pembelajaran khusus sesuai dengan kebutuhan anak berkebutuhan khusus yang ada di kelas(Garnida, 2015). Prinsip khusus bagi siswa tunanetra yaitu prinsip kekonkritan, prinsip pengalaman yang menyatu, dan prinsip belajar sambil melakukan.

Permasalahan yang terjadi pada siklus I terkait pembagian kelompok telah diperbaharui dan menjadikan proses pembelajaran siklus II berjalan lebih baik. Diskusi kelompok menjadi lebih hidup dan tutor lebih dapat berperan saat pembelajaran siklus II. Pada pembelajaran siklus II, penulis telah memberikan feedback terhadap hasil diskusi kelompok dan latihan soal. Hasil penelitian siklus II sudah meningkat dari hasil pada siklus I. Namun masih ada kekurangan dalam pembelajaran siklus II, yaitu sebagian siswa tidak memperhatikan saat ada kelompok yang mempersentasikan hasil diskusi serta tidak memperhatikan saat penulis memberikan feedback terhadap hasil diskusi.

Hasil penelitian pada siklus II telah sesuai dengan indikator keberhasilan penelitian yaitu 1) Persentase rata-rata kelas dalam tes pemahaman konsep meningkat dari siklus sebelumnya dan persentase tiap indikator dalam kategori baik. Dikatakan baik apabila persentase tersebut berada pada interval rentang 60,00 $\leq \mu \leq 79,99$ dan 2) Persentase rata-rata kelas dalam motivasi belajar siswa meningkat dari siklus sebelumnya dan persentase tiap indikator dalam kategori tinggi. Dikatakan tinggi apabila persentase tersebut berada pada interval rentang 60,00 $\leq \mu \leq 79,99$. Karena kedua indikator keberhasilan penelitian tersebut tercapai, maka penelitian diberhentikan. Berdasarkan hasil refleksi siklus II bahwa penerapan pembelajaran matematika melalui model tutor sebaya dengan pendekatan saintifik dapat meningkatkan pemahaman konsep dan motivasi belajar siswa di kelas inklusif.

\section{KESIMPULAN}

Berdasarkan hasil analisis data dan pembahasan dapat disimpulkan bahwa model tutor sebaya dengan pendekatan saintifik yang diterapkan pada saat pembelajaran matematika di kelas VII E SMP Negeri 2 Sewon dapat meningkatkan pemahaman konsep dan motivasi belajar siswa. Kelas VII E merupakan salah satu kelas inklusif yang terdapat satu siswa dengan gangguan penglihatan dalam kategori siswa kurang awas atau low vision. Peningkatan tersebut dapat dilihat dari persentase rata-rata kelas dalam pemahaman konsep siklus I yaitu $45 \%$ menjadi $75 \%$ pada siklus II dan persentase rata-rata kelas dalam motivasi belajar siswa siklus I mencapai $69 \%$ menjadi $70 \%$ pada siklus II. Pembelajaran yang dilaksanakan di kelas VII E secara umum sama seperti pembelajaran pada umumnya serta mengimplementasikan prinsip-prinsip khusus pembelajaran untuk siswa tunannetra. Hal ini untuk memfasilitasi siswa low vision yang ada di kelas VII E secara khusus dan siswa lain pada umumnya. Prinsip-prinsip khusus tersebut yaitu: prinsip kekonritan, prinsip pengalaman yang menyatu, dan prinsip belajar sambil melakukan. Wujud pengimplementasian prinsip-prinsip khusus dalam penelitian ini yaitu penggunaan media pembelajaran berupa bangun-bangun segiempat. 


\section{REFERENSI}

Anggorowati, N. P. (2013). Penerapan Model Pembelajaran Tutor Sebaya pada Mata Pelajaran Sosiologi. Komunitas: International Journal of Indonesia Society and Culture, 3(1), 103-120. https://doi.org/10.15294/komunitas.v3i1.2303

Garnida, D. (2015). Pengantar Pendidikan Inklusif. Bandung: Refika Aditama.

Kurniati, A., \& Sari, A. (2019). Pengaruh Penerapan Model Pembelajaran Kooperatif Tipe Numbered Heads Together (NHT) terhadap Kemampuan Pemahaman Konsep Matematis Ditinjau dari Kemandirian Belajar Siswa. JURING (Journal for Research in Mathematics Learning), 2(2), 137-147. https://doi.org/10.24014/juring.v2i2.7494

Musfiqon, H., \& Nurdyansyah. (2015). Pendekatan Pembelajaran Saintifik. Sidoarjo: Nizamia Learning Center.

Noryanti, T., Mz, Z. A., \& Nufus, H. (2019). Pengaruh Penerapan Metode Tutor Sebaya Terhadap Kemampuan Pemecahan Masalah Matematis Berdasarkan Kemampuan Awal Matematis. Jurnal Pijar Mipa, 14(3), 102-107. https://doi.org/10.29303/jpm.v14i3.1072

Retnowati, D., \& Murtiyasa, B. (2013). Upaya Meningkatkan Pemahaman Konsep dan Disposisi Matematis Menggunakan Model Pembelajaran Treffinger. Presented at the Seminar Nasional Pendidikan Matematika, Surakarta.

Sari, A., \& Yuniati, S. (2018). Penerapan Pendekatan Realistic Mathematics Education (RME) terhadap Kemampuan Pemahaman Konsep Matematis. Jurnal Cendekia: Jurnal Pendidikan Matematika, 2(2), 71-80. https://doi.org/10.31004/cendekia.v2i2.49

Sudijono, A. (2012). Pengantar Evaluasi Pendidikan. Jakarta: Raja Grafindo Persada. 